\title{
Tourist Behaviour Choosing Homestay In Bali
}

\author{
Dewa Ayu Made Lily Dianasari ${ }^{1}$, Ni Made Tirtawati ${ }^{2}$, I B Putra Negarayana ${ }^{3}$, Hanugerah K L ${ }^{4}$, \\ I Gede Gian Saputra ${ }^{5}$, Dewa Ayu Nyoman Aridayanti ${ }^{6}$ \\ $\left\{\right.$ lily.dianasari2001@gmail.com $\left.{ }^{1}\right\}$
}

Sekolah Tinggi Pariwisata Nusa Dua Bali, Jl. Dharmawangsa, Benoa, Kec. Kuta Sel., Kabupaten Badung, Bali,
Indonesia $^{123456}$

\begin{abstract}
Homestay is a special characteristic for tourists who want a cultural experience in a destination. Homestay contributions can directly touch the community at the lower level. Tourism in Bali leads to the development of a community-based homestay. In the development of homestay, tourists are faced with various homestay products. This research will be conducted in Badung, Gianyar, Buleleng and Karangasem Regencies. These four locations are chosen based on the existence of homestay that has been developed for a long time and in terms of quantity has been adequate for the needs of tourists. Questionnaires were distributed as many as 400 respondents in the four research sites. The behavior of foreign tourists in choosing a homestay in Bali is preferring a homestay for the reason of seeking a new adventure, the price is the main basis, search for homestay information also through the media social, and new experiences. When using the homestay, the first impression of tourists when in the homestay is good and the average length of stay 2-3 nights. After using the homestay, travelers will recommend the homestay that has been used through social media with Tripadvisor selected at most as a place to give a review of his experience after using the homestay, and more recommend it to friends and family, and the experience most remembered by tourists is local culture
\end{abstract}

Keywords: Tourist Behaviour; Travel Motivation; Tourist Experience

\section{Introduction}

The role of tourists is very significant in realizing the development of tourism destinations in an area or region. Tourism exists because of tourists, so the study of tourists is one focus in the sociology of tourism. In the components of the tourism system, tourists are the first component. Tourists play a very important role in the development of tourism itself. Without tourists, tourism will "stall" so that all development related to the world of tourism can not run smoothly [1]. Tourists travel to a place because of the driving factors and pull factors from where they want to visit. Consciously or not, during this time only paid attention from how they spend their money. So not a few who know how the behavior of tourists actually. Often also seen the tendency of tourists to choose new places and they do not know. In the destination visited, tourists will perform various tourist activities that become characteristics of their respective regions. Saputra, I Gede Gian and Sukana reveals that destinations such as Ubud in Bali, European tourists perform activities such as choosing a place to stay, choosing a place to eat, experience cultural and looking for entertainment [2]. It is interesting that most European tourists choose homestay as their place to stay when in Ubud and Bali. Homestay is a special characteristic for travelers who want a cultural experience in a destination.

Currently, homestay becomes a priority program by the Ministry of Tourism based on homestay contributions that can directly touch the community at the bottom level. Therefore, tourism in Bali leads to the development of a community-based homestay. It is also very popular with tourists. The tourists stay at the homestay to gain the experience of Balinese society and culture will be increasingly felt. In the tourism development, tourists are faced with various homestay products. This certainly provides such varied variations on the image of the homestay itself. In the end, this will create an image for tourists towards homestay which essentially form the image of Bali tourism. Therefore, research on the behavior of tourists in choosing a homestay becomes essentially needed. In addition to enriching academic studies, this study is expected to find a variety of tourist behaviors including obstacles faced by tourists in choosing a homestay in Bali. 


\section{Method}

This research uses qualitative approach supported by quantitative data. This research is explorative to analyze the behavior of foreign tourists in choosing homestay in Bali. The behavior in question is the activity of tourists before, during and after using the homestay. The study was designed to further explore information from the behavior of foreign tourists including the obstacles encountered when using a homestay in Bali.

The research was conducted in Bali Province, by taking sample area in four regencies, are Badung, Gianyar, Buleleng and Karangasem. These four locations are chosen based on the existence of homestay that has been developed for a long time and in terms of quantity has been adequate for the needs of tourists. Data collection technique is done by field observation, interview, survey and literature study. The sample is part of the total population, sampling of foreign tourists visiting Bali especially who have been staying in homestay in their current visit by using proportional purposive sampling technique as much as 400 respondents with distribution 120 in Gianyar regency, 120 in Badung regency, 80 in Karangasem regency and 80 in Buleleng Regency.

\section{Results and Disscusion}

\subsection{Tourist Behavior}

Morrison defines that, the behavior of tourists is a changing of choosing the activities and facilities when they use and act after buying goods and services of tours [3]. According to Michael Solomon Gary Bamossy Søren Askegaard Margaret K. Hogg the behavior of travelers is "a process involving the selection, purchasing, use, or determination of one's or group's goods, services, ideas or experiences to meet their travel needs [4]. Tourist behavior is the key to sustaining all marketing activities undertaken for the development, promotion and selling of tourism products and the process of learning why people buy the products they buy and how to make those decisions. Susan Horner and John Swarbrooke argue that "Tourist behavior is a process that includes when individuals or groups choose, buy and use, organize products or services, planning or experience, to meet their needs and wants [5] ." In this study the definition of tourist behavior refers to the understanding of Solomon but rather devoted in looking at how tourists before before buying tourism products (homestay), when using and after using homestay. Foreign tourists in question are tourists who come from outside Indonesia.

\subsection{Travel Motivation}

According to Pitana that: Motivation is fundamental in the study of tourists and tourism, because motivation is a "trigger" of the travel process, although this motivation is often not fully realized by tourists itself [6]. Basically someone travels motivated by several things, the motivations can be grouped into four major groups as follows:

a. Physical or Physiological Motivation is a physical or physical motivation, for example for relaxation, health, comfort, participate in sports activities, relax and etc.

b. Cultural Motivation is the desire to know the culture, customs, traditions and other regional arts. Including interest in various objects of cultural heritage.

c. Social or Interpersonal Motivation is a social motivation, such as visiting friends and family, meeting partners, doing things that are considered to bring prestige, make pilgrimages, escape from boring situations and so on.

d. Fantasy Motivation that is the motivation that in other areas sesorang will be able to escape from the daily routines are dull and that give psychological satisfaction [6] [7].

\subsection{Respondent Profile}

International tourists who visit is dominated by male but the comparison is not significant. In addition, it is also known that tourists who come from Germany have the highest number of visits compared to other countries of origin of tourists. Viewed in terms of age, tourists who visit is a productive tourist, which is in the age range 20-30 years. Tourists who visited are dominated by professionals who first use homestay as a means of accommodation. The visit is done with friends and organize their own journey, therefore the source of information obtained about the homestay is dominated by internet and social media sought by the tourists themselves. International tourists who become respondents are dominated by tourists from Europe such as Germany, UK, and France. Respondents were also aged 20-30 years old with a percentage of 71\%, with more professional and student types, traveling with friends or by themselves, and had incomes between USD 1,0012,000, who visited Bali only once two years ago. 


\subsection{Tourists Experience before Staying in Homestay}

Before staying in a homestay, the tourist prefer adventure experience with gain value with $47 \%$ of total respondents. This can be interpreted that more tourists who stay in homestay are tourists who belong to the group alocentric or mid-centric. The experience in question is an experience that has never been previously received from previous trips before. In addition to adventure, culture and become a backpacker also has a relatively large percentage, which is $24 \%$ and $28 \%$. This means that for Bali as a cultural tourism destination is still an important reason for tourists, including in the choice of accommodation for tourists. While being a backpacker can be seen as a more enjoyable journey in getting more experience.

In choosing accommodation, the factors that most influence homestay accommodation selection are price and score of the review, with percentage of 59\% and 19\% respectively. Price is the most important factor for tourists in choosing a homestay. The cheaper the price of homestay room rent will be more inviting tourists to choose the homestay. The abundance of homestays with varied variations in price makes it easy for tourists to choose homestays to use. Supported by reviews from tourists who have used the homestay will be able to convince tourists to choose the homestay. Other factors such as facilities, accessibility, service, etc. are not of great concern or influence for tourists in choosing a homestay. Saputra, I Gede Gian, Tirtawati Ni Made state homestay is not the main attraction, but the facilities will make the tourist feel comfort during the stay in Bali .

For the selection of homestay before making the tour, the most important role in choosing to stay in the homestay is in the tourists themselves, followed by friends and spouses / family. This means friends and spouses / families have a large enough role in influencing tourists in choosing a homestay to be used. Tourists also more materials always use social media as a medium to make reservations with $68 \%$ percentage. Similarly for sources of information used. Social media with a percentage of $45 \%$ to be the main source of information for tourists, followed by sources of information coming from friends to get a recommendation which homestay is good to occupy. Trevel agents and other sources of information such as websites or advertising that are still traditional are very small presentas, only by $1 \%$ and $5 \%$. This can be utilized by the community or homestay owners to pay more attention to reviews or reviews that will be written by travelers who have used their homestay. Homestay owners also have and widely use social media as a marketing communication medium. The choice of social media as a marketing communications medium is due to the ease and cheapness of expenses when compared to using other communication media. Also according to homestay owners, using social media will be easier to bid with a broader target market.

The main reason why tourists used homestay as a means of accommodation compared with other accommodation facilities is an affordable price. While the reasons for interaction with local communities and cultures, or activities offered only by $22 \%, 24 \%$, and $17 \%$. This certainly can be a driving force for homestay owners or managers of tourism destinations to diversify their products so as to attract more tourists to choose homestays as a means of accommodation.

Expectations of tourists staying in more homestays are gaining new or different experiences from those previously owned by $63 \%$. The new experience in question is the experience of getting a new or different atmosphere like the homestay environment and the services and facilities offered by the homestay owners. The experience of travelers before stay can be seen in Table 1.

Table 1. International Tourist Experience Before Stay in Homestay

\begin{tabular}{rllc}
\hline No & \multicolumn{1}{c}{ Most Tourist Experience } & \multicolumn{1}{c}{$\begin{array}{c}\text { Persentage } \\
(\%)\end{array}$} \\
\hline 1 & Value & Adventure & 47 \\
2 & Factors that most influence accommodation selection & Price & 59 \\
3 & The most important person in choosing to stay at the homestay & Her/Him self & 63 \\
4 & How often to use social media to make reservations & Always & 68 \\
5 & Homestay Information Sources & IT/ Media Social & 45 \\
6 & The main reason for choosing a homestay as accommodation in & Price & 41 \\
7 & Bali & New Expectations of staying in homestay & \multicolumn{2}{c}{ Source: Data Proccessed, 2018 }
\end{tabular}

\subsection{Tourist Experience During Stay at Homestay}

For the tourist experience during the stay in homestay, the first impression of more tourists get a good experience, although more are the first time tourists use homestay as a means of accommodation. This can be regarded as both an attraction and an incentive to improve the guest repeater or the level of visits to the destination. There is no negative first impression or disappointment, even the impression of comfort and hospitality received and perceived by the tourists get a percentage of $21 \%$ and $11 \%$. 
The length of stay of tourists who use homestay as a means of accommodation on average is 2-3 nights with a percentage of $72 \%$. There are even $4-7$ nights with a percentage of $21 \%$. This is very good for homestay owners and tourism destinations where the homestay is located. The longer the tourists spend the night on a destination, the expenditure will also be incurred will increase, with the increase of tourist expenditure then the economic impact on society will also increase. There are even some tourists staying overnight than 7 nights, although still relatively small at 3\%. It is expected that the length of stay of these tourists by the owners of tourists can be much longer.

Tourist expenditures incurred by tourists during their stay in homestay vary greatly, from $<$ IDR 500,000 with a percentage of $27 \%$, IDR $500,000-1,000,000$ with a $24 \%$ percentage, IDR 1,000,000 - 3,000,000 with $41 \%$ percentage, and up to $>$ IDR 3,000,000 with a percentage of $8 \%$. These travelers spend more on paying homestay rent and meeting daily needs such as eating and drinking. The expenditure of tourists is considered sufficient for homestay owners and sometimes even more, given not so many facilities and activities that homestay owners can offer tourists during their stay in their homestay. The experience of tourists during their stay at the homestay can be seen in Table 2 .

Table 2. International Tourist Experience During Stay in Homestay

\begin{tabular}{rllc}
\hline No & \multicolumn{2}{c}{ Most Tourist Experiences } & Percentage $(\%)$ \\
\hline 1 & First impressions stay at homestay & Good & 60 \\
2 & Length of stay in Homestay & $\mathbf{2 - 3}$ nights & 72 \\
3 & Expences during saty in homestay & IDR 1.000.000 - 3.000.000 & 41 \\
4 & Activities during stay in homestay & Heritage Tourism & 21 \\
\hline
\end{tabular}

Source: Data Proccesed, 2018

For activities undertaken by tourists during stay in homestay is also very beervariasi. Most are activities related to cultural heritage activities $(21 \%)$. This activity is the most activities offered to tourists, such as the routine and daily routine of homestay owners or community-related cultures. In addition to heritage tourism activities, there are also Marine Tourism, Eco Tourism, Adventure Tourism, Art \& Culinary Tourism, Urban \& Rural Tourism, MICE \& Event Tourism, Sport \& Health Tourism, and Integrated Area Tourism. For MICE \& Event Tourism activities get the lowest percentage of $3 \%$ because very rarely this activity is done in homestay except on homestay which has relatively more room number. If any, tourists who use or do this activity are group tourists or students who do activities together.

\subsection{Tourist Experience After Stay In Homestay}

After staying at the homestay, tourists will give more reviews about their experiences during the stay, whether positive or negative, and the provision of this review is done online. Even some of the reviews are accompanied by value-giving. This will have an impact on the recommendation and credibility of its homestay for other travelers, especially for travelers who need information when staying at the homestay. Tourists who give reviews about this experience has a very large percentage of $77 \%$., While the rest will not make a review. This can be a very good thing if the reviews of the tourist experience give a positive impression. On the contrary, if the reviews of the tourists experience negative feeding will be bad for the homestay. Because the entire review results will be accessible and readable from all cybercriminals. The experience of tourists after staying at the homestay can be seen in Table 3 .

Tabel 3. Tourist Experiences After Stay in Homestay

\begin{tabular}{|c|c|c|c|}
\hline No & Most Tourist Experiences & & Percentage $(\%)$ \\
\hline 1 & $\begin{array}{l}\text { Will make an online review about the experience of staying } \\
\text { at this homestay }\end{array}$ & Yes & 77 \\
\hline 2 & Social Media used to write reviews & Tripadvisor & 60 \\
\hline 3 & What comes to mind after staying at a homestay & Good Service & 40 \\
\hline 4 & Would recommend to others about this homestay & Yes & 89 \\
\hline 5 & To whom would recommend about the experience of & Friends & 57 \\
\hline
\end{tabular}


staying at the homestay

6

How to recommend the experience of staying in homestay Share On

to others Sosmed

Local Culture

7 The most memorable experience about homestays

Source: Data Proccesed, 2018

The media that will be a place for travelers to write their most reviews on social media Tripadvisor by $60 \%$ followed by Instagram and Facebook. These three social media are chosen by many tourists as a place to write their suggestion that the three social media is the most widely used by travelers as a place to share information about tourist travel tourists. $89 \%$ of travelers will recommend homestays that they have used with others. Most parties that will be recommended by tourists are their friends and family. This again demonstrates the importance of homestay owners to pay attention to their marketing communications through word of mouth through travelers who have used their homestay either verbally or through electronic media such as the internet with their social media. Recommendable in social media by $57 \%$ and verbal direct by $42 \%$. It can also indicate that tourists also have the desire as soon as possible to provide their reviews and experiences after staying at the homestay. The most memorable experience and remembered by tourists after staying at the homestay is local culture or local culture that they get. The percentage of homestay service and friendliness is $17 \%$ and $15 \%$. Although relatively not too large, but service and hospitality remain an added value in improving satisfaction and good experience as long as tourists stay at homestay.

\section{Conclusion}

The behavior of foreign tourists in choosing a homestay in Bali is preferring a homestay for the reason of seeking a new adventure, at a price that is the main basis, more likely to decide homestay to be used from its own tourists, who always use social media and search for information homestay also through the media social, in the hope of gaining new experiences of different data. When using a homestay, the first impression of a traveler when in the homestay is good, the average length of stay is 2-3 nights, with spending on the average homestay of IDR 1,000,000 - 3,000,000, and the most varied but the most activities related to cultural activities. After using the homestay, travelers will recommend the homestay that has been used through social media with Tripadvisor selected at most as a place to give the reviews about his experience after using homestay, and more recommend to friends and family, and the experience most remembered by tourists is local culture .

\section{References}

[1] Leiper N, Oct. 1979 The framework of tourism: Towards a definition of tourism, tourist, and the tourist industry Ann. Tour. Res. 6, 4 p. 390-407.

[2] Saputra, I Gede Gian and Sukana I M, 2013 Kajian Perilaku Wisatawan Eropa First Timer dan Repeater di Kelurahan Ubud Destin. Pariwisata 1, 1 p. 25-33.

[3] Morrison A M, 2013 Marketing and Managing Tourism Destinations .

[4] Michael Solomon Gary Bamossy Søren Askegaard Margaret K. Hogg, 2006 Consumer behaviour .

[5] Susan Horner and John Swarbrooke, 2007 Consumer Behaviour in Tourism 2nd ed., 39, 5 Oxford: Elsivier Ltd.

[6] Peter E Murphy, 1985 Tourism: A Community Approach (RLE Tourism) 1st Editio, 2013 London: Routledge.

[7] Saputra, I Gede Gian, Tirtawati Ni Made D D A M L, 2018, Homestay dan Wisatawan Repeater, in Homestay Mozaik Pariwisata Berbasis Kerakyatan, 1st ed., P. D. S. Mertha I Wayan dan Pitanatri, Ed. (Badung: Pusat Penelitian dan Pengabdian kepada Masyarakat Sekolah Tinggi Pariwisata Nusa Dua Bali), p. 400. 